\title{
An Empirical Study on Mobile Phone usage among Young Adults in Ghana: From the Viewpoint of University Students
}

\author{
Albert Akanlisikum \\ Akanferi \\ Lecturer, Department of \\ Information Technology \\ Studies, \\ University of Professional \\ Studies, UPSA
}

\author{
Lawrence Kwami Aziale \\ Lecturer, Department of \\ Information Technology \\ Studies, \\ University of Professional \\ Studies, UPSA
}

\author{
Isaac Asampana \\ Lecturer, Department of \\ Information Technology \\ Studies, \\ University of Professional \\ Studies, UPSA
}

\begin{abstract}
Mobile phones have become part and parcel of the lives people across the globe. Moreover, there are varying uses of mobile phones across different social classes including young adults of school-going age. This study investigated the usage of mobile phones among young adults of public tertiary institutions in Ghana. A quantitative research approach was used. Accidental sampling technique was used to select 1000 participants. A self-administered questionnaire was used to collect data from participants. It was found that young adults use their mobile phones more frequently for making and receiving calls, for browsing the internet, chatting on websites like Watsapp, multimedia messaging and listening to music and radio. Young adults use mobile phones for entertainment rather than business and education-related functions. They have therefore become obsessed to functions of the mobile phone such as listening to music and messaging with Watsapp, facebook and the like. There is the need for young adults to gear mobile phones towards doing more of academic and career-related works.
\end{abstract}

\section{General Terms}

Pattern Recognition

\section{Keywords}

Mobile phones, young adults, cost of use, purpose of use

\section{INTRODUCTION}

A mobile phone (also known as a cellular phone, cell phone and a hand phone) is a device which can make and receive telephone calls over a radio link whilst moving around a wide geographic area. Recent studies suggest that cell phones have evolved into something more than a simple communication tool, gaining its own place in various aspects of social interaction. Some studies revealed that cell phones play an integral part in the lives of young people [1].

\footnotetext{
Mobile devises seems to have invaded the universe. At every turn, you see a mobile devise in use by someone. This technology has permeated even such distant reaches of the world as never imagined before. The International Telecommunication Union [2], reported that there will be 5.3 billion mobile subscriptions by the end of 2010. This is approximately the equivalent of 77 percent of the world population. This represents a huge increase from 4.6 billion mobile subscriptions at the end of 2009. For the developing world, it is estimated that by the end of 2010 there will be 3.8
}

billion mobile subscriptions, representing 73 percent of global subscriptions.

Africa has not been left out in the last decade; Africa experienced a mobile telephone revolution. It could be said that the continent actually "leapfrogged" fixed-line telephone systems with mobile telephone.

Ghana in less than a decade has seen tremendous growth in the cellular telephone industry. Today, a cell phone is no longer the rich man's preserve accessory in Ghana. People of different ages, economics status, educational qualification, and sex now own and use mobile phones. In Ghana, cell phone penetration rate has increased to $80.5 \%$ in August 2011 from $74.2 \%$ in December 2010 [3]. Almost everyone has a mobile phone in his or her pocket. The first cellular phone service in Ghana was initiated by Mobitel in 1992. In that year alone, 19,000 Ghanaians owned mobile phones. In 1998 the number of mobile phone users in the country increased to 43,000 and by the middle of 1999 the number increased to 68,000 .

The adoption of the mobile phone by young people is a global phenomenon in recent years. This gadget has been transformed from a technological tool to a social tool and now fully integrated into the daily lives of people of all walks of lives, especially the adolescent.

This evolving technology has given rise to concerns over both social and etiquette and workplace propriety of the usage behaviour. The question one asks is whether this phenomenon has any impact on social relations.

\section{RESEARCH PROBLEM}

In less than a decade there has been tremendous growth in the cellular telephone industry in Ghana. Today, a cell phone is no longer a rich man's preserve accessory in Ghana. Cell phone penetration rate in Ghana has increased to $80.5 \%$ in August 2011 from 74.2\% in December 2010 [3]. Now, people of all ages, economic status, educational backgrounds, sex and indeed in various standings use the cell phone.

The adoption of the cell phone especially, by young people is a global phenomenon in recent years. It has turned from a technological tool to a social tool and now a fully integral part of young adults' daily lives. The cell phone itself offers several positive impacts to our lives. The mobile phone has 
allowed us to create a network of communications [4]. According to [4], it is the very essence of mobility in media as it allows instantaneous interactive communication over long distances. The cell phone device offers us security, safety, accessibility and other benefits [5]. It is also seen as a possibility of spur-of-the-moment business or casual meetings and also through the mobile data services that allow you to find where other people are located in a building or surrounding area [6].

However, this evolving technology has given rise to concerns over both social and workplace propriety cell phone usage behaviour. The questions one asks is whether this phenomenon has any impact on social relations and operations at workplaces.

\section{PURPOSE OF STUDY}

This study intends to investigate the perception of cell phone usage propriety among young adults in the university community. It will study how the cell phone affects social relations and etiquette. In this context it was essential to pursue the following specific objectives:

1. To identify the common type of handset set preferred and the cost involved

2. To assess the reasons for purchasing a mobile phone

3. To assess the most common uses of the mobile phone by respondents

\section{RESEARCH HYPOTHESES}

The following alternative hypotheses were tested in this study:

H1: The amount of money spent by male young adults on mobile phones in a month is more than that spent by female young adults.

$\mathrm{H} 2$ : Working young adults spend more money on mobile phones than non-working young adults.

H3: Amount of money spent on mobile phones differs across age groups.

H4: Amount of money spent on mobile phones differs across national affiliations.

\section{LITERATURE REVIEW}

Several established models and theories have been used to explore the adoption of technological products and services. As far as mobile devices are concerned, [7] proposed and validated a model on adoption which was based on the Theory of Reasoned Action [8] the Technology Acceptance Model (TAM) [9] and two non-utilitarian motives. The two proposed several antecedents to attitude towards use (perceived expressiveness, perceived enjoyment, perceived usefulness, perceived ease of use, and normative pressure).

The [7] model is the basis for investigation in this study. It has been demonstrated to be robust across age groups, gender and mobile service categories. The current investigation seeks to understand the perceptions of university student groups that are currently using mobile devices with various applications and tools. Perceived Ease of Use: The degree to which an individual "believes that using a particular system would be free of efforts" [9].

\subsection{Demography and Phone Usage}

According to [10], the youth was very quick in the adoption of the mobile phone even before it has been in existence for about a decade. Reduction in costs, size and the introduction of the pre-paid phone card in the 1990's contributed to the surprisingly rapid adoption rate by young people [5]. The world over, the rates of mobile phone use amongst young people is on the increase, see table 1 below:

Table 1: Ownership of mobile phones across the world

\begin{tabular}{|l|l|l|l|}
\hline Country & Year & Age Group (years) & Statistics \\
\hline Norway & 1999 & $13-20$ & $80 \%$ \\
\hline $\begin{array}{l}\text { United } \\
\text { Kingdom }\end{array}$ & 2001 & $<16$ & $90 \%$ \\
\hline Italy & 2003 & $9-10$ & $56 \%$ \\
\hline \multirow{4}{*}{ Australia } & \multirow{2}{*}{2004} & $5-9$ & $\begin{array}{l}50,000 \\
\text { children }\end{array}$ \\
\cline { 3 - 4 } & & $10-13$ & $33 \%$ \\
\cline { 3 - 4 } & & $13-15$ & $45 \%$ \\
\hline
\end{tabular}

Even though the use of mobile phone would have been linked to business activities, research has shown that the age group 16 - 24 years are the most prevalent users [11]; [12]; [13] According to [14] the choice of mobile phones based on features and attributes are influenced by demographic factors. [15] agreed that there are several factors including demographics, technology-related skills, and culture that are determinants of mobile phone usage and having an influence on the decision to adopt and use them. They further stated that the age of a mobile phone adopter is a determinant to the choice of mobile technology data features. According to them "age, or stage in life, seemed to influence the manner in which the mobile device users balanced the expenses and convenience associated with mobility. The degree to which a mobile phone user has the confidence in using high-tech devices also predicts the behaviour of a mobile phone adopting, this is referred to as Technology self-efficacy. Cultural origin frequently plays a role in defining individuals' patterns of usage of mobile technology.

Mobile technology has text messaging capabilities with symbolic meaning which also influences an individual's usage pattern depending on the users cultural origin, high power distance societies as against lower power distance societies [15].

Another important consideration for the high uptake of the youth of mobile technology may be explained by the relative low price of the technology [16], especially with the discovery of the microchip that revolutionised mobile technology. Coverage of mobile phones also makes it attractive to the youth and a probable incentive for them to gravitate towards them and away from landlines [17]. Proliferation of mobile phone service providers that increased competition and pushed down call cost, and allowing transfer of several data types amongst each other such as photos or video snippets [17]. It has even been estimated that the number of adolescents owing a mobile phone is likely to surpass their parents [10].

\subsection{Factors affecting the reasons for purchasing a mobile phone}

Literature abounds on the subject of reasons on the use of mobile phones but are mostly in relation to its impact on society rather than on the individual [18]. [18] have put the reasons into simple (convenience, personal efficiency and 
security) and complex (information immediacy, contactability, social interaction and social control). The subject of reasons that influence why people acquire and use mobile phones has been blurred by its prevalence and impact on their everyday lives and becoming a necessity. The mobile phone is now viewed as an extension of people's personality, reflecting their personal preferences and identity [18].

\subsection{Important Features/Attributes and Functionalities/Applications of Mobile Phone Influencing Purchase}

The mobile phone has come quite a long way from its beginning in the early 1980s when it was the size of a small briefcase [17]. However, the mobile phone today is sleek, fitting into the palm and offered in rainbow of colours and full of features. Mobile phone users now have a number of features to choose from: ring tones, browsers, wireless cameras, instant messaging, streaming video, mobile music, push-to-talk (walkie-talkie), television clip playing, college entrance exam preparation review, over-the air music downloads and full-length videos. This is not the end, according to [19], more is still to come, the mobile phones may in the very near future even be used as credit cards.

[20] defined attributes as: “(i) mobile phone applications, which focus on the actions that can be performed (such as sending/receiving text messages); and (ii) mobile phone tools, which focus on the applications that can be used (such as an alarm clock feature)". SMS (Short Message Services) is one of the early peripheral features of the mobile phone to be introduced in early 1990s [21]. Subsequently, other features and functions were introduced into the mobile phone. The features and functionalities on a mobile phone influences the decision of users to use the phone [22].

The youth, it is reported have a "symbolic and affective investment" in mobile phones and some even prefer their mobile phone to television or the Internet [10]. The mobile phone is a status symbol for young people. [23] reported that adolescents see the appearance and personalised accessories of their phones as symbols of status with $60 \%$ of adolescents reporting that they will upgrade the features of the phones. The mobile phone is seen as a fashion accessory that satisfies the need for individualisation by having choices in mobile wallpaper, ring tones, phone covers, carry bags and other accessories [24].

\section{METHODOLOGY}

A survey method was used in this project. The targeted population was students of some selected public and private universities in The Greater Accra Region of Ghana. The survey instrument used in this project was a structured questionnaire. The sample frame was university students from the public and private universities in the Greater Accra Region of Ghana and sample size of 1000 students was selected at random using the accidental technique. The questionnaire captured students' views on the propriety of cell phone usage among young adults in the university community. The Statistical Package for Social Sciences (SPSS) Version 17 was used to analyze the data gathered. Data was gathered from primary data sources.

Non-probability sampling specifically accidental technique was applied in the collection of primary data through the administration of questionnaire. The purpose of the questionnaire was to identify issues of cell phone etiquette and usage propriety of students. The questionnaire was administered over a period of 3 a weeks to cover the broad spectrum of all the students.

Qualitative and quantitative methods were used to analyze data. The qualitative methods involved descriptive indicators to evaluate students' experience the use cell phones. The quantitative methods used were frequency calculations, deduction about sample from population and graphic representation of statistics.

\section{RESULTS}

In this section, findings of the study are presented. Before results are unfolded, it is worth indicating that a response rate of $93 \%$ was achieved in this study. Thus out of 1000 questionnaires administered, 933 were completed and successfully retrieved. A response rate of $93 \%$ is sufficiently high to generate valid findings. Table 2 comes with results on relevant demographic characteristics of respondents.

Table 2: Demographic Characteristics of Respondents

\begin{tabular}{|c|c|c|c|c|}
\hline \multirow[t]{2}{*}{ Block } & & Frequency & $\begin{array}{l}\text { Percentage } \\
(\%)\end{array}$ & $\begin{array}{l}\text { Cumulative } \\
\text { percentage }\end{array}$ \\
\hline & \multicolumn{4}{|c|}{ Gender } \\
\hline \multirow{3}{*}{1} & Male & 493 & 52.8403 & 52.8403 \\
\hline & Female & 440 & 47.1597 & 100 \\
\hline & Total & 933 & 100 & \\
\hline \multirow{4}{*}{2} & \multicolumn{4}{|c|}{ Working status } \\
\hline & Working & 378 & 40.5145 & 50 \\
\hline & Not working & 555 & 59.4855 & 100 \\
\hline & Total & 933 & 100 & \\
\hline \multirow{4}{*}{3} & \multicolumn{4}{|c|}{ Nationality } \\
\hline & Ghanaians & 678 & 72.6688 & 72.6688 \\
\hline & $\begin{array}{l}\text { Non- } \\
\text { Ghanaians }\end{array}$ & 255 & 27.3312 & 100 \\
\hline & Total & 933 & 100 & \\
\hline \multirow{5}{*}{4} & \multicolumn{4}{|c|}{ Age } \\
\hline & $15-20 \mathrm{yrs}$ & 278 & 29.7964 & 29.7964 \\
\hline & $21-25 \mathrm{yrs}$ & 522 & 55.9486 & 85.7449 \\
\hline & Above 25 yrs & 133 & 14.2551 & 100 \\
\hline & Total & 933 & 100 & \\
\hline
\end{tabular}

In Table 2, four demographic attributes are shown. The first block shows the gender of respondents. Evidently, about 53\% of respondents who responded were females, while about $47 \%$ of respondents were males. Interestingly, the difference in the proportions of male and female respondents is not too large to introduce a significant bias in any gender-based comparison. This may apply to other variables in Table 2. The second block shows the working status of respondents. In this regard, about $59 \%$ of respondents were not working, but about $41 \%$ of all respondents were working. The relevance of this demographic variable is that it would form a basis for identifying the effect of working condition on amount spent on mobile phones by young adults.

In the third block, about $73 \%$ of respondents were Ghanaians, whereas the remaining $27 \%$ of respondents were foreigners. 
Therefore, a majority of respondents who responded in this study were Ghanaians. In the third block, the age distribution of respondents spans 15 and more, though most respondents of about $56 \%$ were between the ages of 21 and 25 years. The four demographic variables in this table are relevant for testing the hypotheses of this study.

Table 3: Access to Mobile and Home-based Phones by Respondents

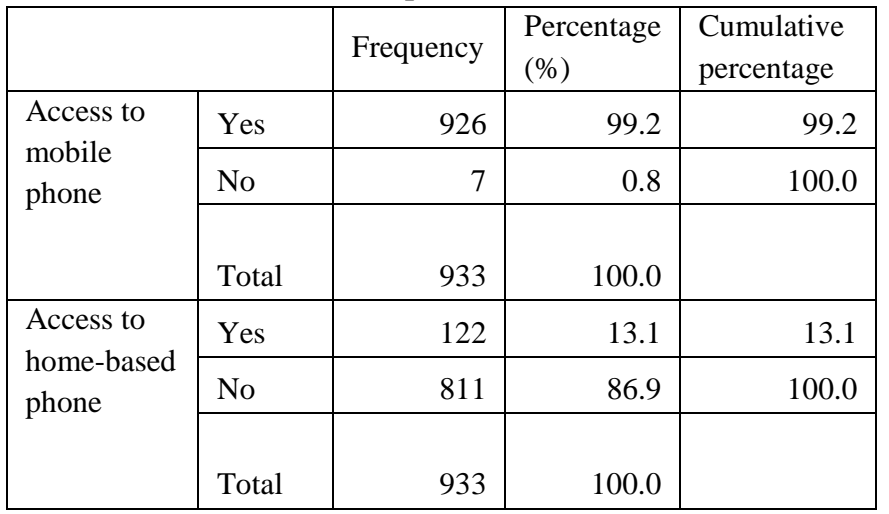

Table 3 indicates access to mobile and home-based phones by respondents. Obviously, an overwhelming majority of $99 \%$ of respondents had access to mobile phones; thus less than $1 \%$ of all respondents did not have access to a mobile phone. However, access to home-based phones is low relative to access to mobile phones, as about $87 \%$ of respondents did not have access to home-based phones. It is therefore likely that the proliferation of mobile phones has reduced access to home-based phones, as well as preference for them. In short, patronage and usage of mobile phones is very high among young adults. Yet, there is uncertainty as to which brands of phones are used by them.

Table 4: Various Brands of Mobile Phones Used by Respondents

\begin{tabular}{|l|r|r|}
\hline & Frequency & Percent \\
\hline NOKIA & 234 & 25.1 \\
\hline SONY Ericsson & 21 & 2.3 \\
\hline TECNO & 98 & 10.5 \\
\hline Motorola & 11 & 1.2 \\
\hline Panasonic & 7 & 0.8 \\
\hline Samsung & 421 & 45.1 \\
\hline LG & 27 & 2.9 \\
\hline Siemens & 3 & 0.3 \\
\hline rLG & 9 & 1.0 \\
\hline Blackberry & 102 & 10.9 \\
\hline Total & 933 & 100.0 \\
\hline
\end{tabular}

Table 4 shows the brands of mobile phones used by young adults in Ghana. From the table, a majority of 54\% of all respondents used Samsung, followed by Nokia (25\%), Blackberry (11\%) and Techno (11\%). Other phones used at the minority level are Sony Ericsson, Motorola, Panasonic, LG, Siemens and rLG. It is likely that respondents patronised Samsung and Nokia at a relatively high extent as a result of their quality, functions and/or price. The influx of China-made
Nokia and Samsung brands in the Ghanaian market might have accounted for the high patronage of these two brands by respondents. This is because China brands come with relatively lower prices in Ghana. Table 5 throws much light on the argument that price influence the patronage of mobile phone brands by young adults.

Table 5: Cost of Mobile Phones used by Respondents

\begin{tabular}{|l|r|r|}
\hline & \multicolumn{1}{|c|}{ Mean } & \multicolumn{1}{c|}{ Std. Deviation } \\
\hline NOKIA & 56.92 & 34.2 \\
\hline SONY Ericsson & 58.45 & 28.1 \\
\hline TECNO & 23.91 & 16.0 \\
\hline Motorola & 45.03 & 10.4 \\
\hline Panasonic & 62.43 & 22.1 \\
\hline Samsung & 55.21 & 20.1 \\
\hline LG & 79.52 & 43.2 \\
\hline Siemens & 43.43 & 19.6 \\
\hline rLG & 32.12 & 13.0 \\
\hline Blackberry & 153.92 & 98.2 \\
\hline Total & 62.094 & 23.1 \\
\hline
\end{tabular}

Table 5 comes with the cost of mobile phone brands patronised by respondents. From the table, the brand with the highest cost is Blackberry $(M=153.92, S D=98.2)$, followed by $\mathrm{LG}(\mathrm{M}=79.52, \mathrm{SD}=43.2)$, and Panasonic $(\mathrm{M}=62.43, \mathrm{SD}$ $=22.1)$. The phone with the lowest cost is Techno $(\mathrm{M}=23.91$, $\mathrm{SD}=16.0$ ), which is one of the most commonly used mobile phones among young adults. Based on evidences in Table 4, most of the most patronised brands have relatively low costs, except Blackberry. Blackberry might have come with the highest cost as a result of the fact that its China version in the market is in limited quantity. However, young adults might prepare using it, perhaps due to its high quality. It is also likely that Blackberry was mostly patronised by employed students, since unemployed students with low financial abilities could not have used Blackberry.

Table 6: Monthly Spending of Respondents on Mobile Phones in Terms of Demographics

\begin{tabular}{|c|l|c|l|l|}
\hline Block & \multicolumn{1}{|c|}{ Gender } & Mean & $\mathrm{t}$ & $\mathrm{p}$-value \\
\hline \multirow{3}{*}{1} & Male & 43.21 & 11.09 & .000 \\
\cline { 2 - 5 } & Female & 21.26 & & \\
\hline \multirow{3}{*}{2} & Working status & Mean & $\mathrm{t}$ & $\mathrm{p}$-value \\
\cline { 2 - 5 } & Working & 62.12 & 19.32 & .000 \\
\cline { 2 - 6 } & Not working & 12.02 & & \\
\hline \multirow{3}{*}{3} & Nationality & Mean & $\mathrm{t}$ & p-value \\
\cline { 2 - 5 } & Ghanaians & 30.12 & 7.01 & .013 \\
\cline { 2 - 5 } & Non-Ghanaians & 42.11 & & \\
\hline
\end{tabular}

Table 6 indicates respondents' monthly spending on mobile phones across three demographic characteristics. In terms of gender, males ( $\mathrm{M}=42.21 \mathrm{GHC})$ spent more on mobile phones in a month relative to females $(\mathrm{M}=21.26 \mathrm{GHC})$. The difference in the spending of males and females is significant at $5 \%$ significance level $(\mathrm{p}=.000)$. Therefore, male young adults significantly spent more money on mobile phones than 
female young adults in a month. Also, at 5\% significance level, working young adults $(\mathrm{M}=62.12)$ spent more money on mobile phones than non-working $(\mathrm{M}=12.02)$ young adults $(\mathrm{p}=.000)$. This result is logical because working young adults would practical have better financial abilities relative to nonworking respondents. Also, non-Ghanaians $(\mathrm{M}=42.11)$ spent more money on mobile phones than Ghanaians $(\mathrm{M}=30.12)$ at $5 \%$ significance level $(\mathrm{p}=.013)$. This might be attributed to the fact that non-Ghanaians have better financial abilities or they spend a lot of money in calling foreign relatives. This argument is justified by the fact that foreign calls are more expensive in Ghana.

Table 7: Monthly Spending of Respondents on Mobile Phones in Terms of Age

\begin{tabular}{|l|r|r|l|l|}
\hline \multicolumn{1}{|c|}{ Age } & \multicolumn{1}{c|}{ Mean } & df & F & p-value \\
\hline $15-20$ yrs & 17.26 & 2 & 15.26 & .000 \\
\hline $21-25$ yrs & 24.81 & & & \\
\hline Above 25 yrs & 36.102 & & & \\
\hline
\end{tabular}

Table 7 is a summary table of an ANOVA test. It verifies if there is a significant difference between the amounts spent on mobile phones in a month by the three age groups. It can be seen that amount spent on mobile phones increased down the group in Table 7. Thus increasing age comes with an increased level of spending. Moreover, there is a significant difference between spending of the three age groups at 5\% significance level $(F=15.26 ; p=.000$. Table 8 comes with the Bonferroni Multiple Comparison Test associated with this test.

Table 8: Summary of Bonferroni Multiple Test

\begin{tabular}{|l|r|}
\hline Pairs sig. & p-value \\
\hline $15-20$ yrs*21-25yrs & .001 \\
\hline $15-20$ yrs*Above 25 yrs & .000 \\
\hline $21-25$ yrs*Above 25 yrs & .000 \\
\hline
\end{tabular}

Table 8 shows summary statistics of Bonferroni Multiple comparison test. This test indicates the extent of difference in the spending of the three age groups in Table 7. Evidently, respondents within the age range of 21 to 25 years spent higher than those within the age range of 15 to 20 ( $\mathrm{p}=.001$ ). Also, respondents who were in the age range of more than 25 spent more money on mobile phones a month than those within the age range of 15 to $20(\mathrm{p}=.000)$ and 21 to $25(\mathrm{p}=$ $.000)$. Therefore, it can be concluded that spending on mobile phone increases with increasing age of young adults.

Table 9: Time Spent Expended on Various Functions of the Mobile Phone

\begin{tabular}{|l|r|r|}
\hline Use & Mean & $\begin{array}{l}\text { Std. } \\
\text { Deviation }\end{array}$ \\
\hline Making and receiving calls & 0.56 & .06 \\
\hline Text and multimedia messaging & 0.34 & .02 \\
\hline Browsing the internet & 3.21 & 1.21 \\
\hline $\begin{array}{l}\text { Chatting on an instant messenger } \\
\text { (eg BBM, Whatsapp, etc) }\end{array}$ & 4.51 & 1.65 \\
\hline Playing games & 0.36 & .21 \\
\hline
\end{tabular}

\begin{tabular}{|l|r|r|} 
Listening to music / radio & 2.09 & 1.02 \\
\hline Taking pictures or video coverage & 0.15 & .001 \\
\hline Wireless / Bluetooth / infra-red & 0.23 & 0.01 \\
\hline Call conferencing & 0.21 & .003 \\
\hline Organizer/schedule/reminders & 0.09 & .001 \\
\hline Reading documents & 0.31 & .11 \\
\hline
\end{tabular}

Table 9 shows various uses of mobile phones by respondents and the average times spent on each use. By principle, these uses constitute the reasons for which young adults purchased the mobile phones. From the table, respondents allocate the highest amount of time to chatting on an instant messenger such as Watsapp; they spend 4 hours and 51 minutes on average using mobile phones to chat a day. The second timeconsuming function of the mobile phone among young adults is listening to music and radio. They spend 2 hours and 9 minutes on average listening to music or radio a day. Business functions such as using mobile phones for scheduling appointments and making reminders attract little time among young adults. Thus they spend just 9 minutes on average in a day on these functions. Obviously, young adults use their mobile phones for entrainment more frequently and much of the time. However, the functions in Table 9 are all forms of uses of mobile phones among young adults, though at varying levels.

Table 10 indicates the frequency of using mobile phones for some functions among young adults. An overwhelming majority of young adults use their mobile phones always for making and receiving calls $(\mathrm{N}=921)$, texting and multimedia massaging $(\mathrm{N}=867)$, browsing the internet $(\mathrm{N}=928)$, chatting on an instant messenger such as Watsapp $(\mathrm{N}=926)$ and listening to music or radio $(\mathrm{N}=921)$. The other functions are less frequently carried out with mobile phones among young adults. Observably, findings in Table 11 corroborate findings in Table 9. For instance, chatting is given must time and is always done among young adults.

Table 11: Respondents ability to live without Mobile Phones

\begin{tabular}{|c|c|c|c|}
\hline & Frequency & $\begin{array}{l}\text { Percentage } \\
(\%)\end{array}$ & $\begin{array}{l}\text { Cumulative } \\
\text { percentage }\end{array}$ \\
\hline Yes & 109 & 11.7 & 11.7 \\
\hline No & 824 & 88.3 & 100.0 \\
\hline Total & 933 & 100.0 & \\
\hline
\end{tabular}

Table 11 indicates if young adults are able to live without mobile phones. In this regard, a majority of $88 \%$ of all respondents disagreed that they can live without mobile phones. Thus most respondents would be able to live without mobile phones, though most of them use mobile phones for entertainment rather than business and education-related functions. However, a few respondents of about $12 \%$ of all respondents agreed that they can live without mobile phones. Obviously, young adults have become obsessed to functions of the mobile phone such as listening to music and messaging with Watsapp, facebook and the like. 
Table 10: Frequency of Carrying out Functions Associated with Mobile Phones

\begin{tabular}{|c|c|c|c|c|c|c|}
\hline Function & Always & Often & $\begin{array}{l}\text { Some } \\
\text { times }\end{array}$ & $\begin{array}{l}\text { Seldom/ } \\
\text { rarely }\end{array}$ & Never & Total \\
\hline Making and receiving calls & 921 & 12 & 0 & 0 & 0 & 933 \\
\hline Text and multimedia messaging & 867 & 19 & 23 & 13 & 11 & 933 \\
\hline Browsing the internet & 928 & 5 & 0 & 0 & 0 & 933 \\
\hline $\begin{array}{l}\text { Chatting on an instant messenger (eg } \\
\text { BBM, Whatsapp, etc) }\end{array}$ & 926 & 4 & 3 & 0 & 0 & 933 \\
\hline Playing games & 16 & 21 & 632 & 234 & 30 & 933 \\
\hline Listening to music / radio & 921 & 12 & 0 & 0 & 0 & 933 \\
\hline Taking pictures or video coverage & 11 & 19 & 23 & 13 & 867 & 933 \\
\hline Wireless / Bluetooth / infra-red & 29 & 5 & 878 & 11 & 0 & 923 \\
\hline Call conferencing & 26 & 4 & 3 & 900 & 0 & 933 \\
\hline Organizer/schedule/reminders & 18 & 11 & 21 & 234 & 649 & 933 \\
\hline Reading documents & 21 & 34 & 13 & 0 & 865 & 933 \\
\hline $\begin{array}{l}\text { While you are talking on your phone, it } \\
\text { bothers you when others around you } \\
\text { talk on their cell phones too }\end{array}$ & 21 & 19 & 867 & 17 & 9 & 933 \\
\hline $\begin{array}{l}\text { You place your phone on 'SILENT' OR } \\
\text { 'VIBRATE' mode }\end{array}$ & 11 & 4 & 918 & 0 & 0 & 933 \\
\hline You use your mobile while driving & 7 & 2 & 3 & 0 & 921 & 933 \\
\hline
\end{tabular}

\section{CONCLUSIONS AND RECOMMENDATIONS}

Based on findings of this study, it is concluded that an overwhelming majority of young adults use mobile phones in Ghana. However, most young adults do not have access to home-based phones. The most patronised mobile phones among young adults include Samsung, Nokia, Blackberry and Techno. Other phones used at the minority level are Sony Ericsson, Motorola, Panasonic, LG, Siemens and rLG. The most expensive mobile phone among these mobile phones is Blackberry, which costs 153.92 cedis on average. This is followed by $\mathrm{LG}(\mathrm{M}=79.52, \mathrm{SD}=43.2)$, and Panasonic $(\mathrm{M}=$ $62.43, \mathrm{SD}=22.1$ ). The phone with the lowest cost is Techno ( $\mathrm{M}=23.91, \mathrm{SD}=16.0)$, which is one of the most commonly used mobile phones among young adults. Most of the most commonly used mobile phones are less expensive; hence their purchase would not pose much economic burdens on young adults.

Male adults significantly $(\mathrm{M}=42.21 \mathrm{GHC})$ spend more on mobile phones in a month relative to females $(\mathrm{M}=21.26$ GHC). Thus, male young adults significantly spend more money on mobile phones than female young adults in a month. Also, working young adults $(\mathrm{M}=62.12)$ spend more money on mobile phones than non-working $(\mathrm{M}=12.02)$ young adults, a situation attributable to financial differences between the two groups. Additionally, non-Ghanaians ( $\mathrm{M}=$ 42.11) spent more money on mobile phones than Ghanaian young adults $(\mathrm{M}=30.12)$ at $5 \%$ significance level. There is a significant difference between the amounts spent on mobile phones in a month by the three age groups. Thus increasing age comes with an increased level of spending. The Bonferroni Multiple comparison test indicates that respondents within the age range of 21 to 25 years spend higher than those within the age range of 15 to $20(\mathrm{p}=.001)$. Also, respondents who are in the age range of more than 25 spend more money on mobile phones a month than those within the age range of 15 to 20 and 21 to 25 . Therefore, it can be concluded that spending on mobile phone increases with increasing age of young adults.

Respondents allocate the highest amount of time to chatting on an instant messenger such as Watsapp; thus they spend 4 hours and 51 minutes on average using mobile phones to chat a day. The second time-consuming function of the mobile phone among young adults is listening to music and radio. In this vein, young adults spend 2 hours and 9 minutes on average listening to music or radio a day. Business functions such as using mobile phones for scheduling appointments and making reminders attract little time among young adults. Young adults therefore use their mobile phones for entrainment more frequently and much of the time.

The most frequent uses of mobile phones among young adults include making and receiving calls $(\mathrm{N}=921)$, texting and multimedia massaging $(\mathrm{N}=867)$, browsing the internet $(\mathrm{N}=$ 928), chatting on an instant messenger such as Watsapp ( $\mathrm{N}=$ 926) and listening to music or radio $(\mathrm{N}=921)$. Most young adults would not be able to live without mobile phones, though most of them use mobile phones for entertainment rather than business and education-related functions. Consequently, young adults have become obsessed to functions of the mobile phone such as listening to music and messaging with Watsapp, facebook and the like.

Young adults must endeavour to gear the use of mobile phones towards accomplishing more productive activities such as doing assignments and career-oriented research. It is recommended that tertiary institutions development programs that would compel young adults to use their mobile phones in doing assignment, since i-phones that have functions for downloading documents such as journal articles and navigating through internet have proliferated. Young adults can be given group assignments whose accomplishment should be limited to using mobile phone functions such as video conferencing. Future researchers are encouraged to 
identify how the use of mobile phones affects the academic performance of young adults, as well as their financial conditions.

\section{REFERENCES}

[1] Walsh, S.P., K.M. White, and M.Y. Ross, Overconnected? A qualitative exploration of the relationship between Australian youth and their mobile phones. Journal of Adolescence, 2008. 31: p. 77-92.

[2] ITU, I.C.U. Committed to connecting the world. 2010 May 2, 2014]; Available from: http://www.itu.int/net/pressoffice/press_releases/2010/39 .aspx\#.U4ot8qh_t1Y.

[3] NCA, N.C.A. Subscriber Base Information for 2010. 2011 [cited 2014 May 2]; Available from: http://www.nca.org.gh/40/105/Market-ShareStatistics.html.

[4] Levinson, P., Cellphone: The Story of the World's Most Mobile Medium and How it Has Transformed Everything! 2004, New York: Palgrave Macmillan.

[5] Ling, R., The Mobile Connection: The Cell Phone's Impact on Society. 2004, Amsterdam: Elsevier, Inc.

[6] Bender, E., Social lives of a cell phone. Technology Review, 2004.

[7] Nysveen, H., P.E. Pedersen, and H. Thorbjornsen, Explaining Intention to use Mobile Chat Services: Moderating Effects of Gender. Journal of Consumer Marketing, 2005. 22: p. 247-256.

[8] Fishbein, M. and I. Ajzen, Belief, Attitude, Intention and Behavior: An Introduction to Theory and Research. 1975, Reading, MA: Addison-Wesley.

[9] Davis, F.D., Perceived usefulness, perceived ease of use, and user acceptance of information technology. MIS Quarterly, 1989. 13(3): p. 319-340.

[10] Campbell, M., The impact of the mobile phone on young people's social life, in Social Change in the 21st Century Conference2005: Centre for Social Change Research Queensland University of Technology. p. 1-14.

[11] Facts, I. n.d. [cited 2014 January]; Available from: http://www.itfacts.biz.

[12] Fitzsimons, G.J., et al., Non-Conscious Influences on Consumer Choice. Marketing Letters, 2002. 13(3): p. 269-279.

[13] Lachance, M.J. and N. Choquette-Bernier, College students' consumer competence: a qualitative exploration. International Journal of Consumer Studies, 2004. 8(5): p. 433-442.

[14] Karjaluoto, H., et al. Exploring Consumer Motives in Mobile Phone Industry: An Investigation of Finnish Mobile Phone users. in Proceedings of the 1st International Conference on Business Economics, Management, and Marketing (Athens, Greece). 2005. Athens, Greece.

[15] 15. Sarker, S. and D.J. Wells, Understanding MOBILE HANDHELD DEVICE USE AND ADOPTION. COMMUNICATIONS OF THE ACM, 2003. 46(12): $p$. 35-40.

[16] Blattberg, R.C. and K.J. Wisniewski, Price-Induced Patterns of Competition. Marketing Science, 1989. 8: p. 1-309.

[17] Lipscomb, T.J., et al., Cellular phone etiquette among college students. International Journal of Consumer Studies, 2005: p. 46-56.

[18] Tian, L., J. Shi, and Z. Yang, Why Does Half the World's Population Have a Mobile Phone? An Examination of Consumers' Attitudes toward Mobile Phones. CYBERPSYCHOLOGY \& BEHAVIOR, 2009. 12(5): p. 513-516.

[19] Crockett, R.O., Will that be cash, credit, or cell? Business Week, 2005. 42.

[20] Head, M. and N. Ziolkowski, UNDERSTANDING STUDENT ATTITUDES OF MOBILE PHONE APPLICATIONS AND TOOLS: A STUDY USING CONJOINT, CLUSTER AND SEM ANALYSES. 18th European Conference on Information Systems, 2010: p. $1-12$.

[21] Market Analysis \& Consumer Research Organisation, A Report on Study of Mobile Phone Usage Among the Teenagers and Youth in Mumbai. MACRO, 2004.

[22] Hakoama, M. and S. Hakoyama, THE IMPACT OF CELL PHONE USE ON SOCIAL NETWORKING AND DEVELOPMENT AMONG COLLEGE STUDENTS. The American Association of Behavioral and Social Sciences Journal (AABSS), 2011. 15: p. 1-20.

[23] Netsafe, The text generation: Mobile phones and New Zealand youth: A report of result from the internet Safety Group's survey of teenage mobile phone use, in Netsafe.2005.

[24] Srivastava, L., Mobile phones and the evolution of social behaviour. Behaviour and Information Technology, 2005. 24: p. 111-129. 